\title{
Vitamins and functional nutrients for extremely low birth weight infants
}

\author{
Gennaro Salvia*, Sabino Moschella, Violante Fonterico, Sonia Di Lena, Giuseppina Mazzarella \\ From XXI Congress of the Italian Society of Neonatology \\ Palermo, Italy. 24-26 September 2015
}

While the need for appropriate post natalgrowth provides many studies focused on macronutrients in the nutrition of preterm infants, the concern for the quality of development of micro premies increases the interest in micronutrients, vitamins and trace elements. Moreover, the ongoing challenge to avoid serious complications of extreme prematurity requires investigations on functional nutrients especially those with antioxidant effect or immunomodulatory properties.

Despite the lack of defined recommendations, much evidence is available.

The antioxidant properties of vitamin A and vitamin $\mathrm{E}$ make these elements important in the nutrition of ELBW infants who are born with a strong deficit of these vitamins. Low plasma vitamin A concentrations increases the risk of chronic lung disease and long-term respiratory disabilities in preterm infants. Vitamin $\mathrm{E}$ counteracts peroxidation of polyunsaturated fattyacids in lipid layers of cell membranes[1].

Preterm infants are exposed to a special risk for metabolic bone disease also due to maternal deficiency and difficulty achieving adequate enteral intake of calcium, phosphorus, and vitamin $\mathrm{D}$. The link between vitamin $\mathrm{D}$ supplementation, serum 25-OH-D concentration and long term outcome inpreterminfants are poorly understood. Some findings supportthe opinion that a vitamin D intake of 800-1000 IU/day is necessary in preterm infants while higher doses are needed in newbornof mothers with vitamin D deficiency [2]. Furthermore, vitamin D plays a rolein physiological processes that affect neuromuscular and immune functions, heart, lung, pancreas, and brain.

Many trials reported enhanced visual acuity and better cognitive performance in the short-term assessments of preterm infants fed formulas supplemented with long

\footnotetext{
* Correspondence: salvia.gennaro@fbfna.it

Neonatal Intensive Care Unit, Buon Consiglio Fatebenefratelli Hospital, Naples, Italy
}

chain polyunsaturated fattyacids(LCPUFA) [3-5]. However, there are many questions about the appropriate dosages and some doubts on the long-term advantages $[6,7]$. Among strategies for the prevention of NEC and sepsis through the use of immunonutrients, lactoferrin [8] and probiotics[9] are getting a place in clinical practice. Other studies will be needed to assess the extension of the evidence currently observed, especially for neonatesin low NEC rates settings. To date are available only weak evidence about the efficacy of arginine and glutamineto prevent intestinal mucosal injury in high risk infants [10]. Lutein supplementation for preterm infants raises plasma concentrations to those observed in human milk fed term infants and ensures the benefit of anti oxidant effect of carotenoidson immature retina and developing brain. Larger trials are needed to determine the best methods of administration to affect the retinopathy of prematurity[11].

\section{Published: 24 September 2015}

\section{References}

Rev Nutr Diet 2014, 110:152-66

2. Kislal FM, Dilmen U: Effect of different doses of vitamin $D$ on osteocalcin and deoxypyridinoline in preterm infants. Pediatrlnt 2008, 50:204-7.

3. Henriksen C, Haugholt $\mathrm{K}$, Lindgren $\mathrm{M}$, et al: Improved cognitive development among preterm infants attributable to early supplementation of human milk with docosahexaenoic acid and arachidonic acid. Pediatrics 2008, 121(6):1137-1145.

4. Makrides M, Gibson RA, McPhee AJ, et al: Neurodevelopmental outcomes of preterm infants fed high-dose docosahexaenoic acid: a randomized controlled trial. JAMA 2009, 301(2):175-182.

5. Smithers LG, Gibson RA, McPhee A, Makrides M: Higher dose of docosahexaenoic acid in the neonatal period improves visual acuity of preterm infants: results of a randomized controlled trial. Am J ClinNutr 2008, 88(4):1049-1056.

6. Almaas AN, Tamnes CK, Nakstad B, et al: Long-chain polyunsaturated fatty 135(6):972-980.

7. Collins $C T$, Gibson RA, Anderson PJ, et al: Neurodevelopmental outcomes at 7-years' corrected age in preterm infants who were fed high-dose 
docosahexaenoic acid to term equivalent: a follow-up of a randomised controlled trial. BMJ Open 2015 Mar 18, 5(3):e007314.

8. Pammi M, Abrams SA: Oral lactoferrin for the prevention of sepsis and necrotizing enterocolitis in preterm infants. Cochrane Database Syst Rev 2015 Feb, 20(2):CD007137.

9. AlFaleh $\mathrm{K}$, Anabrees J: Probiotics for prevention of necrotizing enterocolitis in preterm infants. Cochrane Database Syst Rev 2014 Apr, 10(4):CD005496.

10. El-Shimi MS, Awad HA, Abdelwahed MA, Mohamed MH, Khafagy SM, Saleh G: Enteral L-Arginine and Glutamine Supplementation for Prevention of NEC in Preterm Neonates. Int J Pediatr 2015, 856091.

11. Rubin LP, Chan GM, Barrett-Reis BM, et al: Effect of carotenoid supplementation on plasma carotenoids, inflammation and visual development in preterm infants. J Perinatol 2012 Jun, 32(6):418-24.

doi:10.1186/1824-7288-41-S1-A38

Cite this article as: Salvia et al: Vitamins and functional nutrients for extremely low birth weight infants. Italian Journal of Pediatrics 2015 41(Suppl 1):A38.

\section{Submit your next manuscript to BioMed Central} and take full advantage of:

- Convenient online submission

- Thorough peer review

- No space constraints or color figure charges

- Immediate publication on acceptance

- Inclusion in PubMed, CAS, Scopus and Google Scholar

- Research which is freely available for redistribution

Submit your manuscript at www.biomedcentral.com/submit 